\title{
Effects of Anabolic Steroids on the Histological Structure of Renal Cortex of Adult Male Albino Rats and the Possible Protective Role of Taurine
}

\author{
Mary Refaat Isaac
}

Department of Anatomy and Embryology, Faculty of Medicine, Ain Shams University

\begin{abstract}
Introduction: Misuse of anabolic androgenic steroids (AAS) has become a widespread health problem with subsequent multisystem adverse effects. However, among their adverse effects, renal toxicity remains one of the least discussed.

Aim of work: To study the histopathological effects of Nandrolone Decanoate (ND) abuse on renal cortex and examine the possible protective role of taurine.

Materials and methods: Thirty-six adult male albino rats, aging 4-6 months and weighing $200-250$ gms, were used in this study. Animals were divided equally into three groups; Group I (control group): subdivided into Subgroup IA: negative control and Subgroup IB: rats received intramuscular $0.5 \mathrm{ml}$ sesame oil twice weekly for six weeks and Subgroup IC: received $100 \mathrm{mg} / \mathrm{kg} /$ day Taurine by gavage, for six weeks. Group II (ND Group): received intramuscular $5 \mathrm{mg} / \mathrm{kg}$ ND, dissolved in sesame oil, twice weekly for six weeks. Group III (Taurine and ND Group): given both Taurine and ND in the same dose and duration as subgroup IC and group II respectively. At the end of the experiment, venous blood samples were collected from the tail vein for biochemical assays. Kidneys were dissected out and processed for light and electron microscopic examination. Results: Examination of group II revealed marked congestion, obliteration of Bowman's space and lumina of both proximal and distal tubules. Ultrastructural distortion was evident in glomerular filtration barrier and tubular lining cells. Statistically significant biochemical changes were also observed. However, group III showed almost preserved glomerular and tubular architecture with few persistent changes. Biochemical results also revealed marked improvement.

Conclusion: Marked renal cortical affection with renal functional deterioration were noted following ND. Taurine exerted marked reno-protection thus, it would be also of great help to protect AAS users against possible renal hazards in case their AAS use was inevitable.
\end{abstract}

Received: 06 December 2018, Accepted: 16 January 2019

Key Words: Anabolic steroids, renal cortex, taurine.

Corresponding Author: Mary Refaat Isaac, PhD, Department of Anatomy and Embryology, Faculty of Medicine, Ain Shams University, Egypt, Tel.: +20 1001171964, E-mail: drmaryrefaat@yahoo.com

ISSN: $1110-0559$, Vol. 42, No. 2

\section{INTRODUCTION}

Anabolic androgenic steroids (AAS) are synthetic cholesterol derivatives of testosterone that are therapeutically used in cases of hypogonadism, breast cancer, anemia and various chronic catabolic states ${ }^{[1]}$. Owing to their anabolic effects, AAS fall within a group of self-administered performance-enhancing drugs which are currently used in high doses among bodybuilders for cosmetic reasons and among athletes to enhance performance ${ }^{[2]}$.

However, AAS abuse is an evolving problem that has been blamed for a wide range of side effects the most famous of which are the cardiovascular ones including; hypertension, atherosclerosis, left ventricular dysfunction, thromboembolic events, life-threatening arrhythmia up to sudden cardiac death. In addition; endocrine dysfunction, psychiatric and behavioral disturbances and hepatic and renal toxicities were also frequently reported ${ }^{[3 \text { and } 4]}$.
Although we do not have much information on the potential effects of AAS on renal function, some studies have demonstrated that they led to functional changes including; elevation of serum creatinine, blood urea nitrogen and uric acid ${ }^{[5]}$. Moreover, acute renal failure, as a complication of rhabdomyolysis, has been reported by previous studies among body builders using $\mathrm{AAS}^{[6]}$. Additionally, a case of acute renal failure and hemolytic anemia with subsequent secondary malignant hypertension has been recently reported in a male patient with AAS use associated with intense anaerobic exercise ${ }^{[7]}$.

However, among the various reported side effects of supra-physiological dose of AAS, renal toxicity remains the least evaluated one ${ }^{[8]}$.

Regarding; taurine, it's one of the most abundant free intracellular amino acid that is present in many tissues of humans and animals ${ }^{[9]}$. It is found in high concentrations in the brain, retina, liver, myocardium, kidney, skeletal 
muscles and blood cells ${ }^{[10]}$. Among its beneficial effects are; its antioxidative, anti-inflammatory and anti-apoptotic effects in addition to membrane ion exchange modulation, osmoregulation and neurotransmission regulation ${ }^{[11]}$.

Moreover, taurine exerted protective effects on several body organs against heavy metal or drug induced toxicity including; mercury induced hepatotoxicity ${ }^{[12]}$, cadmiuminduced cardiac impairment ${ }^{[13]}$, cadmium-induced oxidative renal dysfunction ${ }^{[14]}$, tamoxifen-induced hepatotoxicity ${ }^{[15]}$ and sodium fluoride induced hepatocyte cytotoxicity ${ }^{[16]}$.

It has been also recorded that taurine exerted preventive effects on experimental type II diabetic nephropathy, through decreasing blood glucose, improving lipid metabolism and stabilizing glomerular basement membrane structure ${ }^{[17]}$. Additionally, Rosca et al., (2016) stated that taurine had the ability to protect against AAS induced hypertension ${ }^{[18]}$.

However, the issue of whether or not taurine exerts a protective role against the histopathological effects of AAS abuse on the renal tissue has not been thoroughly discussed. Therefore, the aim of the present work was to further clarify the effect of AAS abuse on the renal structure and function and examine the possible protective effects of taurine.

\section{MATERIAL AND METHODS}

\section{Drugs}

1. Nandrolone Decanoate: commercially known as Deca-Durabolin, purchased from The Nile Co. for pharmaceuticals - Cairo - Egypt. It was provided in $1 \mathrm{ml}$ ampoules packaging, each containing 25 mg Nandrolone Decanoate. Each ampoule was dissolved in $10 \mathrm{ml}$ sesame oil and every rat was given $0.5 \mathrm{ml}$ by intramuscular injection (in a dose equivalent to $5 \mathrm{mg} / \mathrm{kg}$ body weight) twice a week, for six weeks ${ }^{[19]}$. This route was chosen as the majority of athletes use supraphysiologic doses of intramuscular $\mathrm{AAS}^{[20]}$.

2. Taurine: Taurine was provided in a powder form (Sigma, St Louis, Missouri, USA). Each 100mg were dissolved in $4 \mathrm{ml}$ of normal saline and each rat received $1 \mathrm{ml}$ of the solution daily, in a dose equivalent to $100 \mathrm{mg} / \mathrm{kg} /$ day, by oral gavage ${ }^{[21]}$.

\section{Animals}

Thirty-six adult male albino rats, aging 4 - 6 months and weighing 200 - 250 gms, were obtained from the Animal House of the Bilharzial Research Unit, Ain Shams University. Animals were housed in conventional wiremesh cages in a regulated room temperature about $21 \pm 10^{\circ} \mathrm{C}$, humidity $45-50 \%$, and light/dark cycles. Rats were fed on standard rat diet and allowed free access to water. They were allowed to acclimatize to experimental conditions by housing them for 10 days prior to the experiment. All animal procedures conform the requirements of our institutional Animal Research and Ethics Committee.

\section{Experimental protocol}

Animals were equally divided into three groups as follows:

- Group I (Control Group): It was composed of 12 adult male albino rats and was further subdivided into two subgroups:

- $\quad$ Subgroup IA (Negative control): included 4 rats that were not given any treatment.

- Subgroup IB (Solvent control): included 4 rats that were given $0.5 \mathrm{ml}$ of sesame oil twice weekly by intramuscular injection, for six weeks.

- Subgroup IC (Taurine control): included 4 rats that were supplemented with $100 \mathrm{mg} / \mathrm{kg} / \mathrm{day}$ of Taurine, by oral gavage, for six weeks.

- Group II (Nandrolone Decanoate Treated Group): It included 12 adult male rats that received $5 \mathrm{mg}$ per kilogram ND twice a week by intramuscular injection, for six weeks.

- Group III (Nandrolone Decanoate and Taurine Treated Group): It included 12 adult male rats treated with ND in the same dose and duration as group II and Taurine, in similar doses and for the same duration as that used in the fore mentioned groups.

At the end of the experiment, all rats were anaesthetized using ether inhalation. Venous blood samples of each rat were collected from the tail vein, plasma was separated, used for biochemical assays. Anterior abdominal wall of each rat was opened and the kidneys were dissected out. Specimens of right kidney were processed for paraffin, semithin and ultrathin sections to be examined by the light and electron microscopes.

For light microscopic studies, sections of the kidneys were cut and specimens with $5 \times 5 \mathrm{~mm}$ thickness were immersed in $10 \%$ formaldehyde in distilled water for one week. After fixation, tissues were dehydrated in ascending grades of ethanol, cleared in xylol and embedded in paraffin blocks. Sections of $5 \mu \mathrm{m}$ in thickness were cut and stained with Haematoxylin and Eosin (Hx. \& E.) Stain ${ }^{[22]}$. The sections were examined with an Olympus light microscope and photographed.

For electron microscopic studies, specimens were immediately cut into cubes ( $1 \mathrm{~mm}$ in diameter) and fixed overnight in $2.5 \%$ phosphate-buffered glutaraldehyde $(\mathrm{pH} 7.3)$ at $4^{\circ} \mathrm{C}$. Specimens were then postfixed in $1 \%$ buffered osmium tetroxide for 1-2 hrs, dehydrated in ascending grades of ethyl alcohol, cleared in propylene oxide, and finally embedded in fresh Epon blocks. Semithin sections $1 \mu \mathrm{m}$ in thickness were cut with glass knives on LKB ultramicrotome and stained with $1 \%$ toluidine blue with $\mathrm{pH}$ 7.3. Sections were then examined by an Olympus light microscope to choose the selected areas. Ultrathin sections, $50-80 \mathrm{~nm}$, were cut from selected areas of the blocks on a Reichert ultramicrotome, placed on copper grids and contrasted with uranyl acetate and lead citrate ${ }^{[23]}$. 
These sections were examined using the transmission electron microscope in Electron Microscope Unit, Faculty of Science, Ain Shams University.

\section{Biochemical analysis}

The withdrawn venous blood from each rat was centrifuged with $5000 \mathrm{r} / \mathrm{min}$ for $10 \mathrm{~min}$ by using centrifuge and plasma was collected. Renal function was assessed by measurement of the level of Serum Creatinine and Blood Urea Nitrogen (BUN). Creatinine was measured (the RateBlanked creatinine/Jaffe method) and BUN was measured (kinetic UV assay) using a Roche/Hitachi auto-analyzer. These biochemical studies were done in Ain-Shams Specialized Hospital labs.

\section{RESULTS}

\section{(A) Histological Results}

\section{- Group I (Control Group)}

Examination of sections of the three control subgroups revealed almost similar structure of the renal cortex.

Light microscopic examination of $\mathrm{H} \& \mathrm{E}$ stained sections revealed that the renal cortex was formed of renal corpuscles, proximal and distal convoluted tubules with minimal interstitial tissue in between. Each renal corpuscle appeared to be formed of a glomerulus and Bowman's capsule. The parietal layer of Bowman's capsule was lined by flat squamous epithelium, while its visceral layer invested the glomerulus with intervening Bowman's space clearly detected between these two layers. The glomerulus was formed of a tuft of glomerular capillaries among which, nuclei of mesangial cells were seen. The proximal convoluted tubules appeared to have a narrow lumen lined by columnar epithelium while the distal convoluted ones were lined with cuboidal epithelium and had a relatively wider lumen (Fig.1).

Semithin sections showed that the parietal layer of Bowman's capsule was formed of a single layer of flattened epithelial cells enclosing glomerular tuft of capillaries with Bowman's space in between. The glomerulus showed multiple blood capillaries with nuclei of their endothelial cells together with nuclei of mesangial cells (Fig.2). The proximal convoluted tubules were lined with tall columnar cells with basally situated rounded nuclei and characteristic apical brush border. The Distal convoluted tubules were seen lined by relatively paler low cubical cells (Fig.3).

Ultrastructural examination, showed glomeruli containing capillaries resting on a uniform basement membrane. They were lined by fenestrated endothelial lining and surrounded by podocytes with euchromatic nucleus and multiple major and minor foot processes. Filtration slits were seen between the minor processes of podocytes (Fig.4). Proximal convoluted tubular lining cells rested on a basal basement membrane and had multiple regular apical microvilli. Their cytoplasm contained euchromatic rounded nuclei with prominent nucleoli, surrounded by numerous longitudinally arranged elongated mitochondria (Fig.5). The DCT lining cells rested basally on a thin basement membrane with well-developed basal infoldings and had scarce apical microvilli. Their cytoplasm had euchromatic rounded nuclei, numerous elongated mitochondria (Fig.6).

\section{- Group II (Nandrolone Decanoate Treated Group):}

Light microscopic examination revealed marked distortion of normal cortical architecture. Obliteration of Bowman's space was frequently observed (Fig.7). Moreover, congestion and dilatation of the interstitial blood vessels as well as the glomerular capillaries was detected (Fig.8). Both PCT and DCT had irregular cellular lining pattern (Figs.7 and 8) some of them had ill-defined lumina (Fig.8) while others had defined ones containing exfoliated nuclei (Figs.7 and 8).

Semithin sections revealed notable obliteration of Bowman's space with congested glomerular capillaries among some dense distorted nuclei (Fig.9). Proximal and distal convoluted tubules showed notable distorted architecture with loss of their characteristic linear nuclear arrangement Fig.10). Cytoplasmic vacuolation, shrunken nuclei, loss of brush border and ill-defined lumen were frequently observed in the PCT (Fig.9). Shrunken darkly stained nuclei together with rarefied ones were also seen in the lining of DCT (Fig.10). In addition, numerous large congested blood vessels were frequently encountered (Figs.9 and 10).

Ultrastructural examination, showed marked distortion of structure of the filtration barrier where areas of focal thickening of capillary basement membrane were frequently seen in addition to indistinct endothelial fenestrations. Podocytes appeared with irregular nuclei and notable effacement of their foot processes (Fig.11). Many PCT lining cells appeared resting basally on a relatively thickened basement membrane and appeared to have destructed apical microvilli with intervening vacuoles. Their cytoplasm appeared rarefied with pyknotic nuclei, irregular vacuolar spaces and disorganized mitochondria (Fig.12). The DCT lining cells had electron dense cytoplasm enclosing shrunken nuclei with abnormal chromatin distribution, ballooned mitochondria resting basally on a thin basement membrane with evident extracellular bands of fibrous tissue (Fig.13). Moreover, markedly congested blood vessels were also frequently encountered (Fig.14).

\section{- Group III (Nandrolone Decanoate and Taurine Treated Group):}

Light microscopic examination revealed that most of the renal corpuscles appeared to have the same picture as those of the control rats. Each one was formed of a glomerulus made up of tuft of capillaries surrounded by distinct Bowman's space. The parietal layer of Bowman's capsule was lined by simple squamous epithelium. The PCT and DCT appeared to have some areas of vacuolation in their lining epithelium together with few exfoliated nuclei. However, the dilated congested blood vessels that 
were a frequent sign in group II, were seldom observed in this group (Fig.15).

Semithin sections showed partial preservation of Bowman's space which was seen enclosing glomerular capillaries and nuclei of mesangial cells with occasional shrunken darkly stained nuclei (Fig.16). Most of the PCT appeared lined by columnar cells with vesicular nuclei with almost normal brush border. However, some cells with vacuolated cytoplasm and few shrunken nuclei were also observed. Distal convoluted tubular lining showed alternating normal lightly stained cells with vesicular nuclei with other darkly stained ones with dense nuclei (Fig.17).

Ultrastructural examination, showed almost preserved filtration barrier where capillaries appeared resting on a regular basement membrane with many areas of preserved endothelial fenestrations. However, podocytes still had some nuclear irregularity but their foot processes almost mimicked those of the control ones with filtration slits in between (Fig.18). Proximal convoluted tubular lining cells rested on a uniform yet thickened basement membrane and retained their regular apical microvilli. Their cytoplasm contained euchromatic rounded nuclei surrounded by longitudinally arranged elongated mitochondria with some swollen ones (Fig.19). Lining cells of DCT appeared also with euochromatic nuclei surrounded by cytoplasm containing rounded mitochondria, free ribosomes, some lysosomes in addition to some vacuolar spaces (Fig.20).

\section{(B) Biochemical Results}

Using biochemical studies, in the control group, the mean serum creatinine and BUN levels were measured and their values were mentioned in tables 1 and 2 respectively.

In group II, both serum creatinine level (Table 1) and BUN level (Table 2) showed highly significant increase compared to the control ones.

In group III, both serum creatinine level (Table 1) and BUN level (Table 2) revealed highly significant decrease in their levels but still retained a highly significant and significant difference respectively when compared to the control group.

Comparisons among the biochemical results of the three groups were further illustrated in the hereunder charts (Histograms 1 and 2).

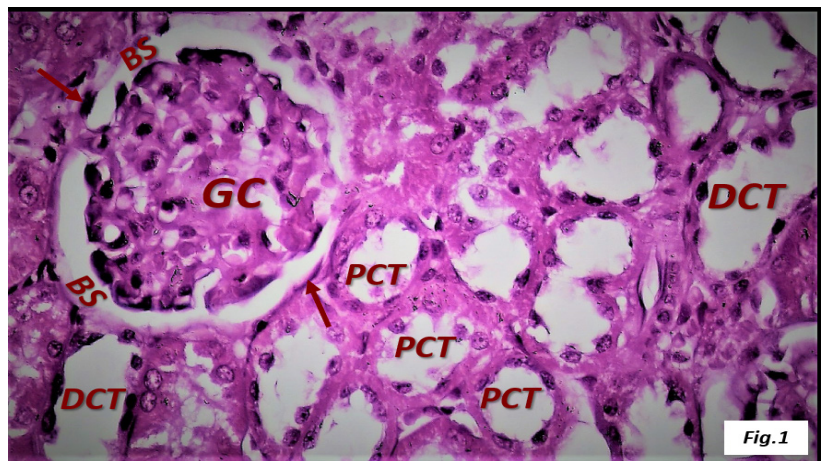

Fig. 1: A photomicrograph of a section of the renal cortex of a rat of group I showing renal corpuscles containing tuft of capillaries (GC) surrounded by Bowman's spaces (BS). The parietal layer of Bowman's capsule is lined by flat squamous epithelium $(\uparrow)$. Notice the proximal convoluted tubules (PCT) and the distal convoluted ones (DCT). (Hx. \& E., x400)

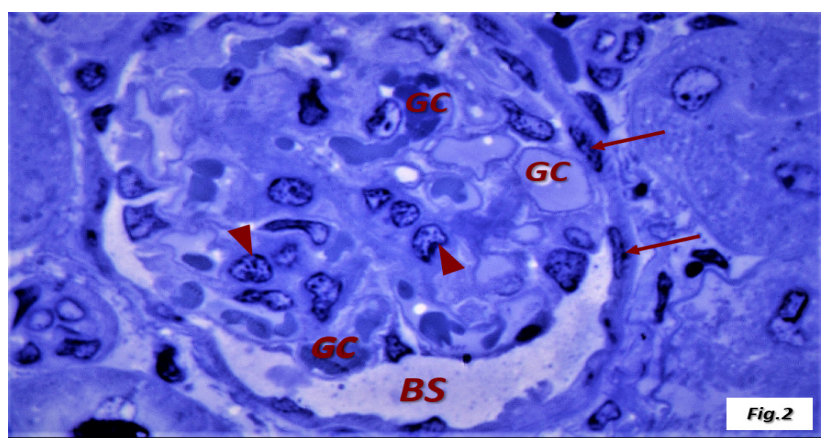

Fig. 2: A photomicrograph of a semithin section of the renal cortex of a rat of group I showing glomerulus lined by a single layer of flattened epithelial cells of Bowman's capsule $(\uparrow)$ enclosing glomerular capillaries $(\mathrm{GC})$ and nuclei $(\boldsymbol{\Delta})$ of endothelial cells and mesangial cells and surrounded by Bowman's space (BS). (Toluidine blue, x1000)

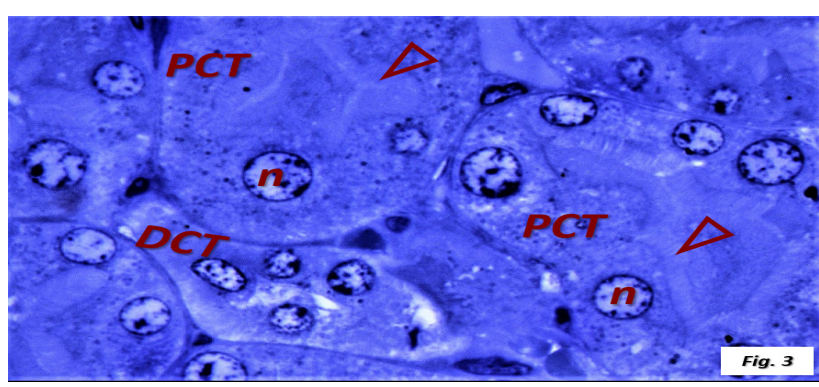

Fig. 3: A photomicrograph of a semithin section of the renal cortex a rat of group I showing PCT (PCT) lined with tall columnar cells with basally situated rounded nuclei (n) and characteristic apical brush border $(\Delta)$. Notice the DCT (DCT) lined by relatively paler low cubical cells (Toluidine blue, x1000) 


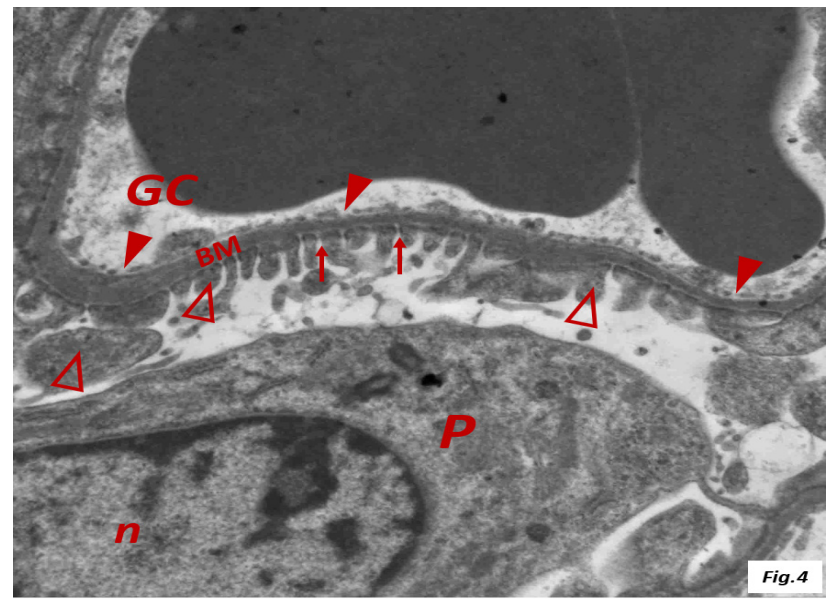

Fig. 4: An electron micrograph of a section of the renal cortex of a rat of group I showing glomerular capillary (GC) with fenestrated endothelial lining $(\mathbf{\Lambda})$ and lying on a uniform basement membrane $(\mathrm{BM})$. Notice the podocyte $(\mathrm{P})$ with euchromatic nucleus $(\mathrm{n})$ and its minor processes $(\Delta)$ with filtration slits in between $(\uparrow)$. (TEM x4000)

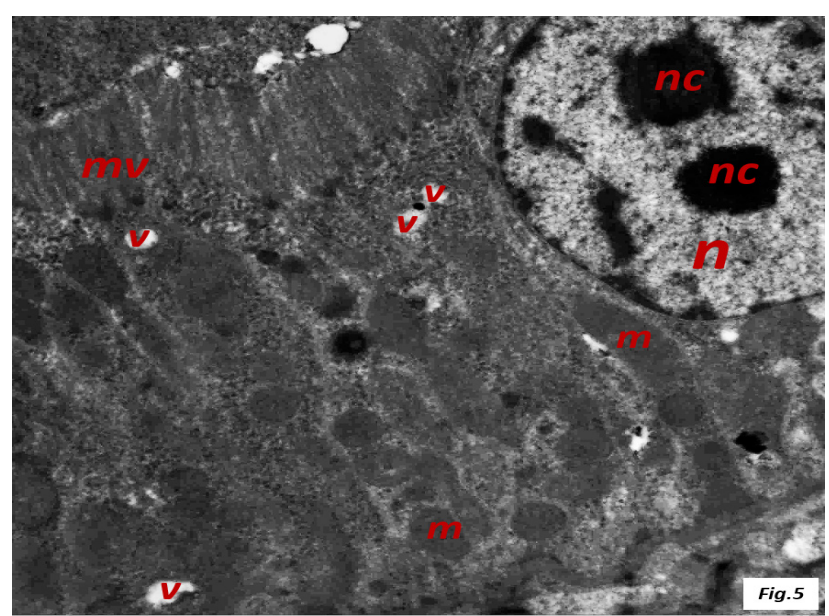

Fig. 5: An electron micrograph of a section of the renal cortex of a rat of group I showing a lining cell of PCT having euchromatic nucleus (n) with two prominent nucleoli (nc). Notice the elongated mitochondria (m), rounded vesicles (v) and regular apical microvilli (mv). (TEM x2500)

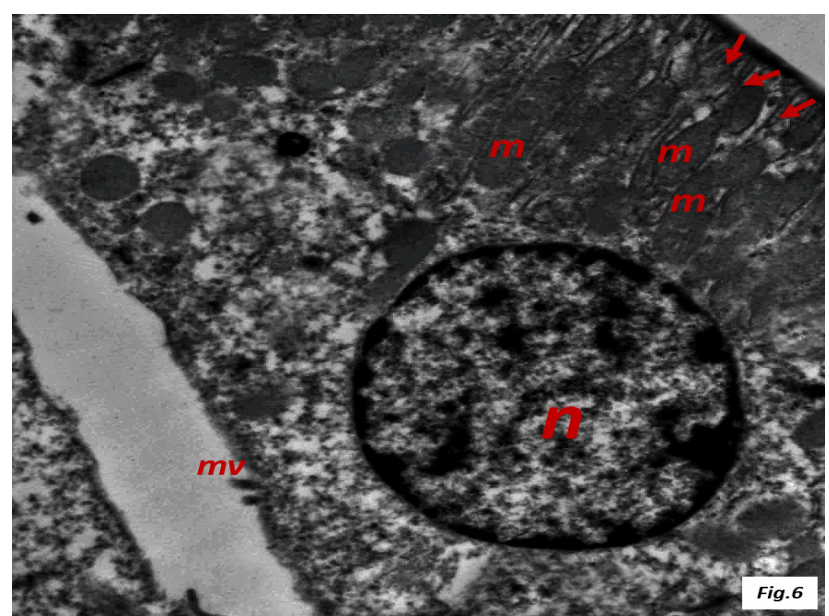

Fig. 6: An electron micrograph of a section of the renal cortex of a rat of group I showing a lining cell of DCT with heterochromatic nucleus (n), basal infoldings $(\uparrow)$, elongated mitochondria $(\mathrm{m})$ and few apical microvilli (mv). (TEM x3000)

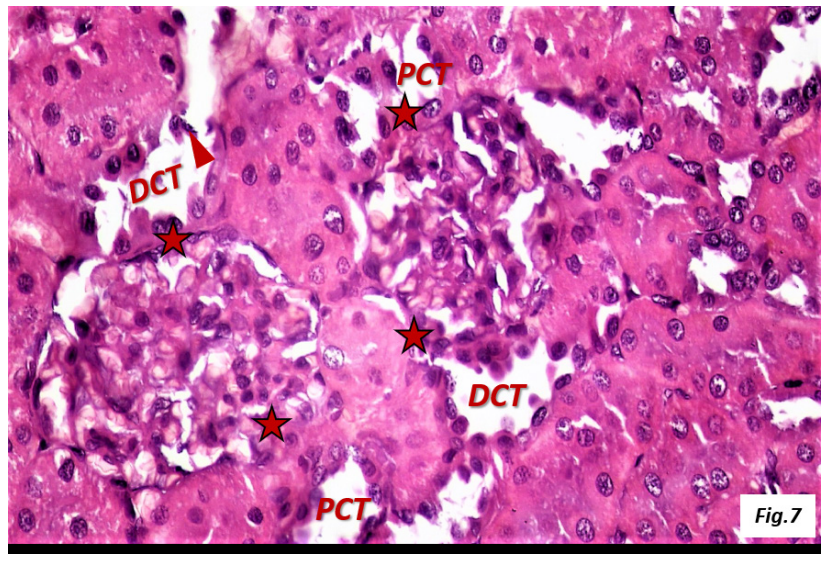

Fig. 7: A photomicrograph of a section of the renal cortex of a rat of group II showing distorted architecture with Bowman's space obliteration $\left(^{*}\right)$. Notice the irregular lining of proximal (PCT) and distal (DCT) convoluted tubules with exfoliated nuclei $(\boldsymbol{\Lambda})$ in the lumen. (Hx. \& E., x400)

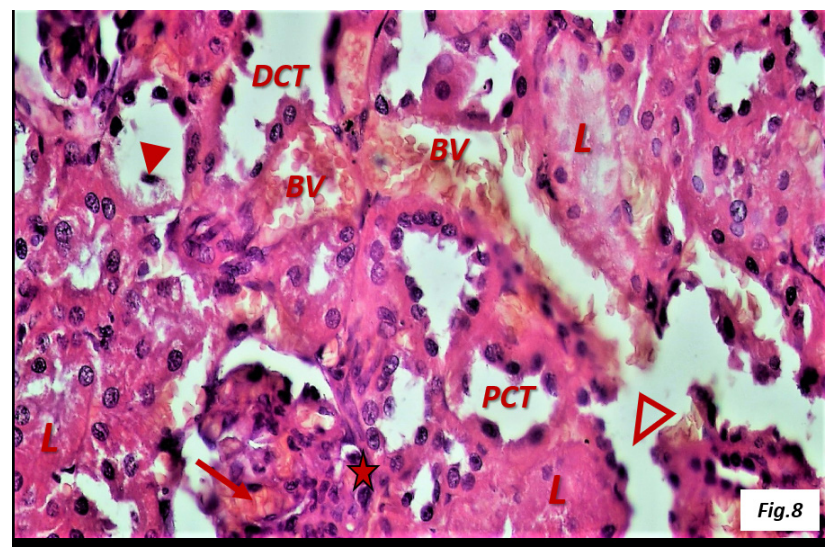

Fig. 8: A photomicrograph of a section of the renal cortex of a rat of group II showing the dilated congested interstitial blood vessels (Bv) and congested glomerular capillaries $(\uparrow)$. Notice the irregular lining of proximal (PCT) and distal (DCT) convoluted tubules, some with illdefined lumina $(\mathrm{L})$ and others with defined ones containing exfoliated nuclei $(\boldsymbol{\Delta})$. Note also the loss of lining continuity of some tubules $(\Delta)$ (Hx. \& E., x400)

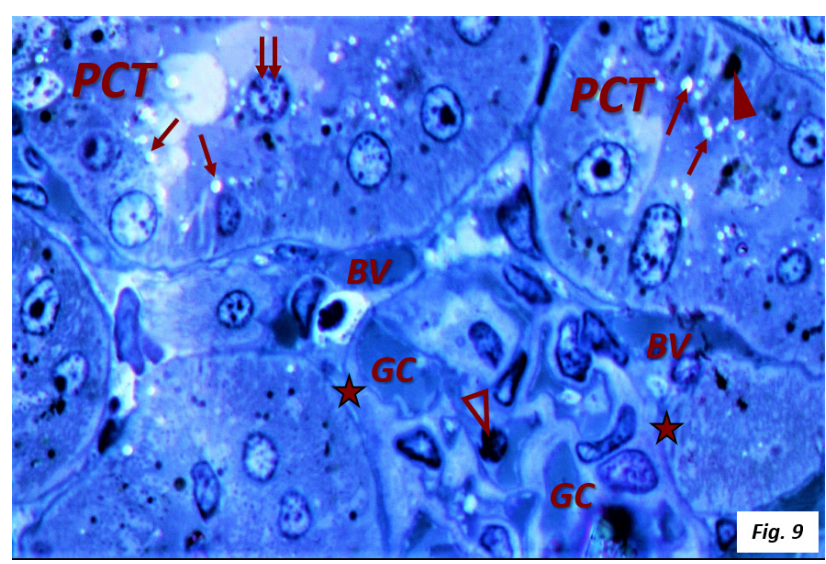

Fig. 9: A photomicrograph of a semithin section of the renal cortex of a rat of group II showing glomerulus with congested capillaries (GC) and dense distorted nuclei $(\Delta)$ with obliteration of Bowman's space $(*)$ Notice the vacuoles $(\uparrow)$, shrunken nuclei $(\boldsymbol{\Lambda})$, an exfoliated one $(\uparrow \uparrow)$ and loss of brush border in the PCT (PCT). Note also the congested blood vessels $(\mathrm{Bv})$. (Toluidine blue, $\mathrm{x} 1000$ ) 


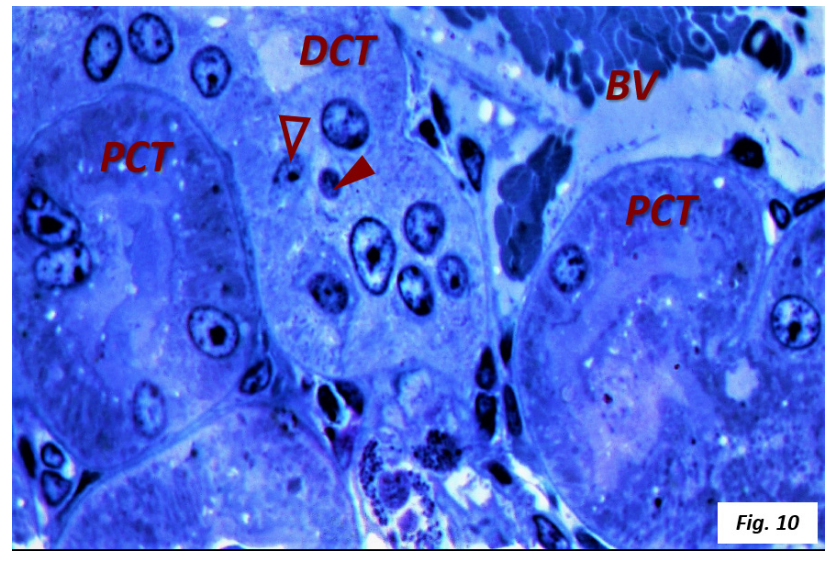

Fig. 10: A photomicrograph of a semithin section of the renal cortex of a rat of group II showing loss of linear nuclear arrangement and ill-defined lumina of proximal (PCT) and distal (DCT) convoluted tubules. Notice the shrunken nucleus $(\boldsymbol{\Delta})$ and the rarefied one $(\Delta)$ in the DCT. Note also the congested blood vessel (Bv). (Toluidine blue, x1000)

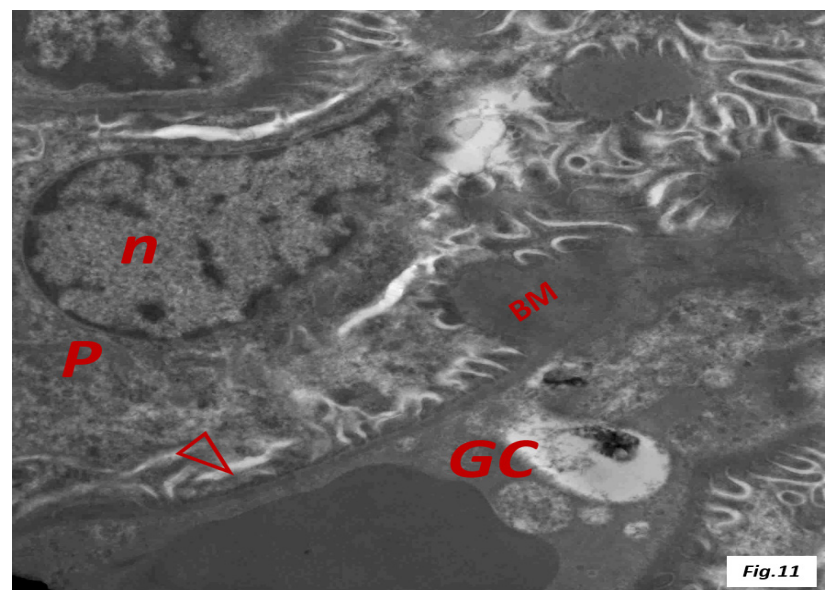

Fig. 11: An electron micrograph of a section of the renal cortex of a rat of group II showing glomerular capillary (GC) with indistinct endothelial fenestrations lying on basement membrane with focal thickening (BM). Notice the podocyte $(\mathrm{P})$ with irregular nucleus (n) and effacement of foot processes $(\Delta)$. (TEM x3000)

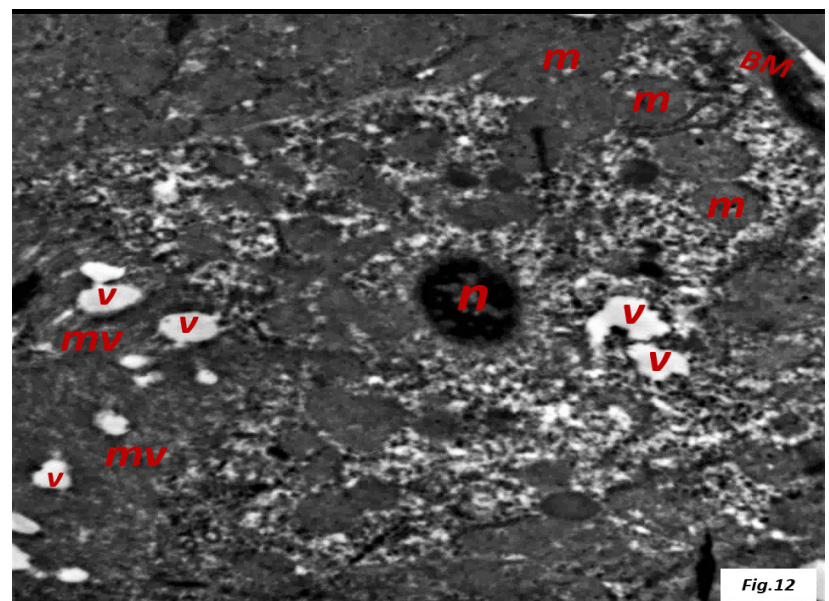

Fig. 12: An electron micrograph of a section of the renal cortex of a rat of group II showing a lining cell of PCT resting on a relatively thickened basement membrane (BM) and containing pyknotic nucleus (n), disorganized mitochondria (m), cytoplasmic vacuoles (v) and destructed apical microvilli (mv) with intervening vacuoles (v). (TEM x2500)

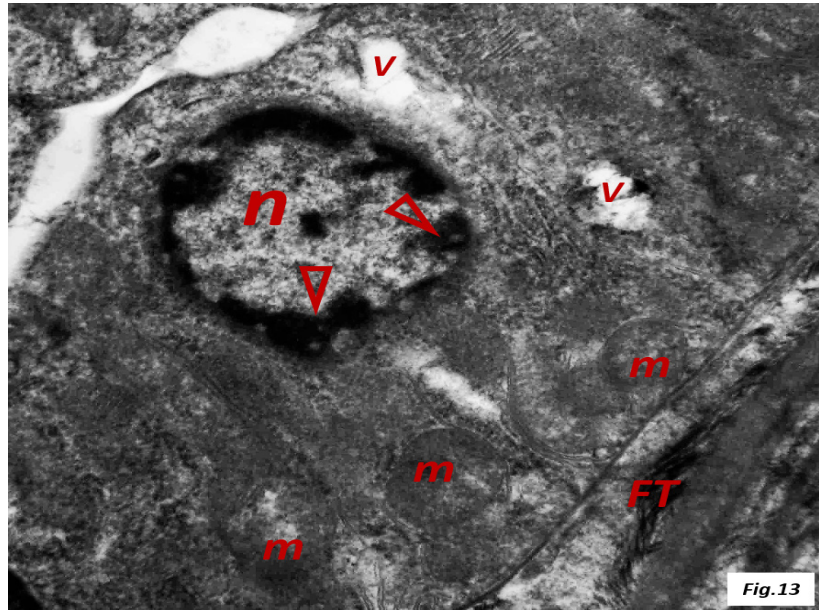

Fig. 13: An electron micrograph of a section of the renal cortex of a rat of group II showing a lining cell of DCT having shrunken nucleus (n) with abnormal chromatin distribution $(\Delta)$. Notice the electron dense cytoplasm with ballooned mitochondria $(\mathrm{m})$, irregular vacuoles $(\mathrm{V})$. Notice the extracellular bands of fibrous tissue (FT). (TEM x4000)

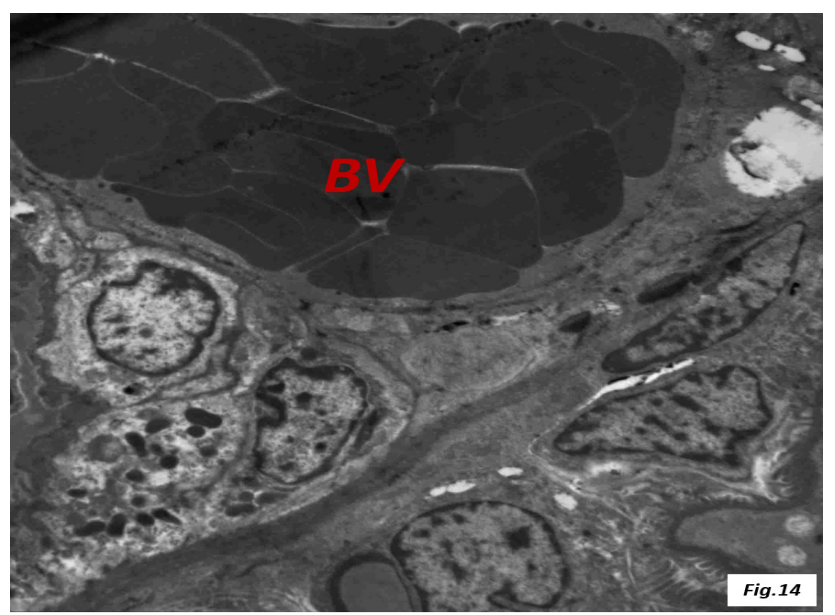

Fig. 14: An electron micrograph of a section of the renal cortex of a rat of group II showing a highly congested blood vessel (BV). (TEM x1500)

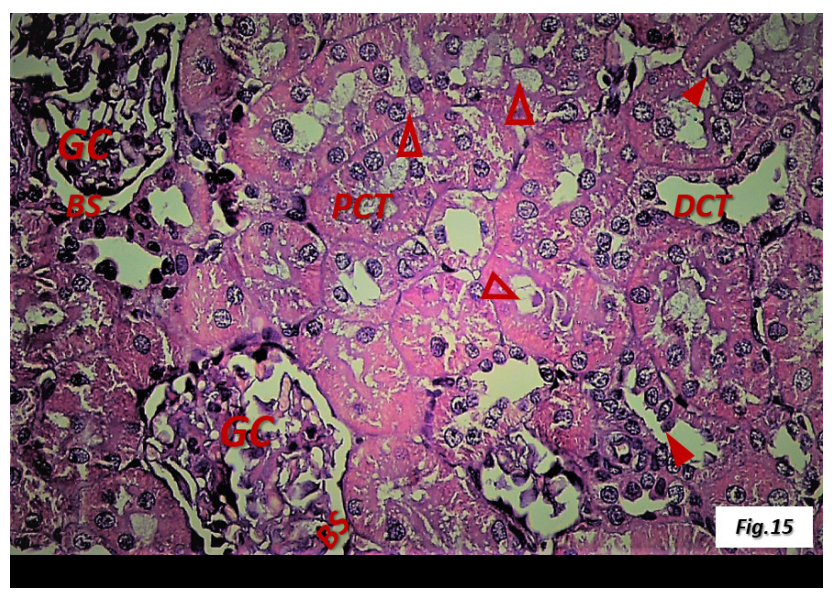

Fig. 15: A photomicrograph of a section of the renal cortex of a rat of group III showing renal corpuscles containing glomerular tuft of capillaries (GC) surrounded by distinct Bowman's spaces (BS). Notice the simple squamous epithelium $(\uparrow)$ lining the parietal layer of Bowman's capsule. Note also the areas of vacuolation $(\Delta)$ in the lining of proximal (PCT) and distal (DCT) convoluted tubules with few exfoliated nuclei (А). (Hx. \& E., x400) 


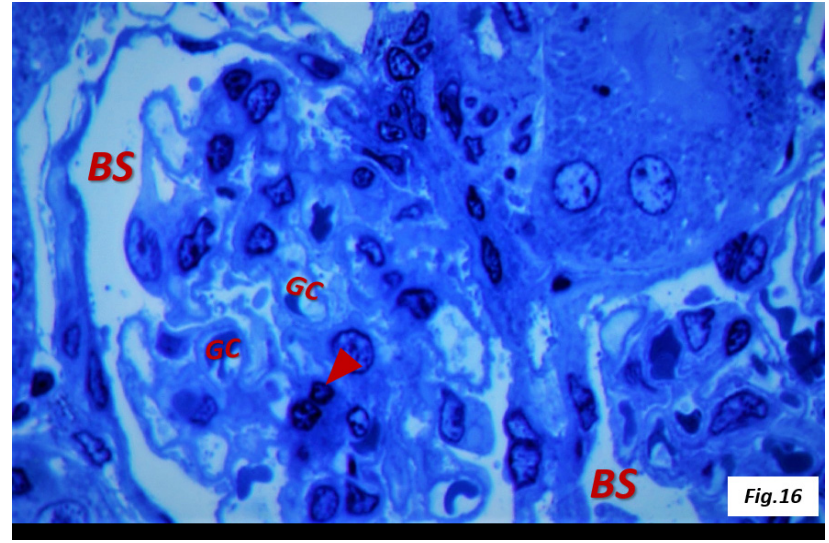

Fig. 16: A photomicrograph of a semithin section of the renal cortex of a rat of group III showing glomeruli enclosing glomerular capillaries $(\mathrm{GC})$ with few dense shrunken nuclei $(\boldsymbol{\Delta})$ and surrounded by preserved Bowman's space (BS). (Toluidine blue, x1000)

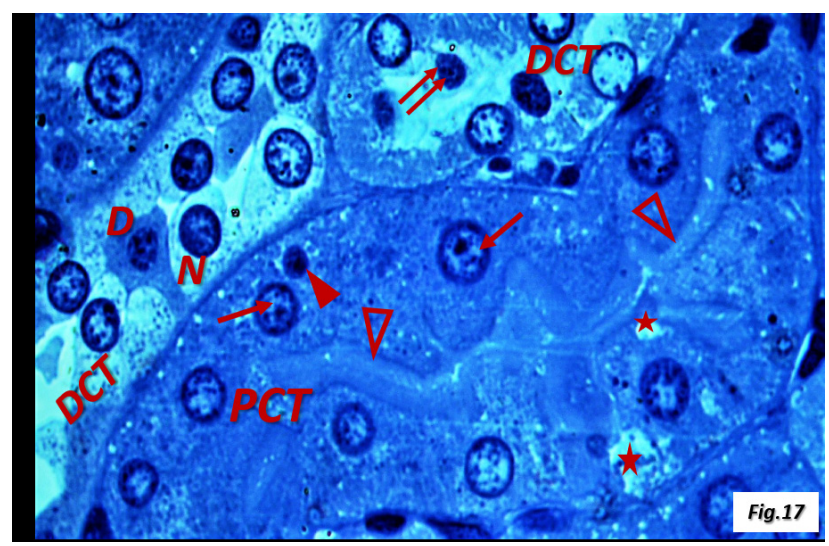

Fig. 17: A photomicrograph of a semithin section of the renal cortex of a rat of group III showing PCT (PCT) with almost preserved brush border $(\Delta)$ and cellular lining with vesicular nuclei $(\uparrow)$, a shrunken one $(\boldsymbol{\Delta})$ and a cell with vacuolated cytoplasm $(*)$. Notice the distal convoluted tubular (DCT) lining with alternating normal lightly stained cells with vesicular nuclei $(\mathrm{N})$ with other darkly stained ones with dense nuclei (D). Note also the exfoliated nucleus $(\uparrow \uparrow)$ in the DCT lumen. (Toluidine blue, x1000)

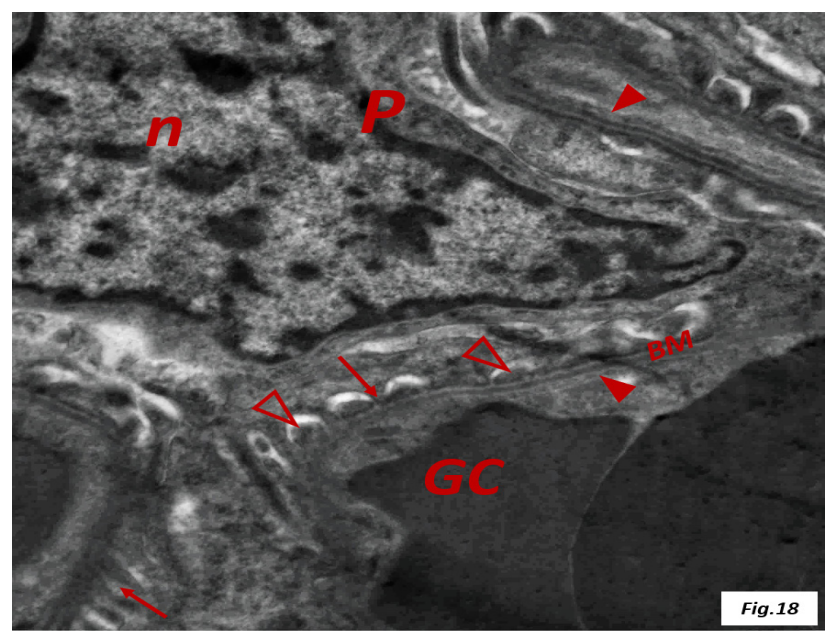

Fig. 18: An electron micrograph of a section of the renal cortex of a rat of group III showing glomerular capillary (GC) with some areas of preserved endothelial fenestrations $(\boldsymbol{\Delta})$. Regular basement membrane $(B M)$ is seen. Notice the podocyte (P) with irregular nucleus (n) and minor foot processes $(\Delta)$ with filtration slits in between $(\uparrow)$. (TEM $\times 4000)$

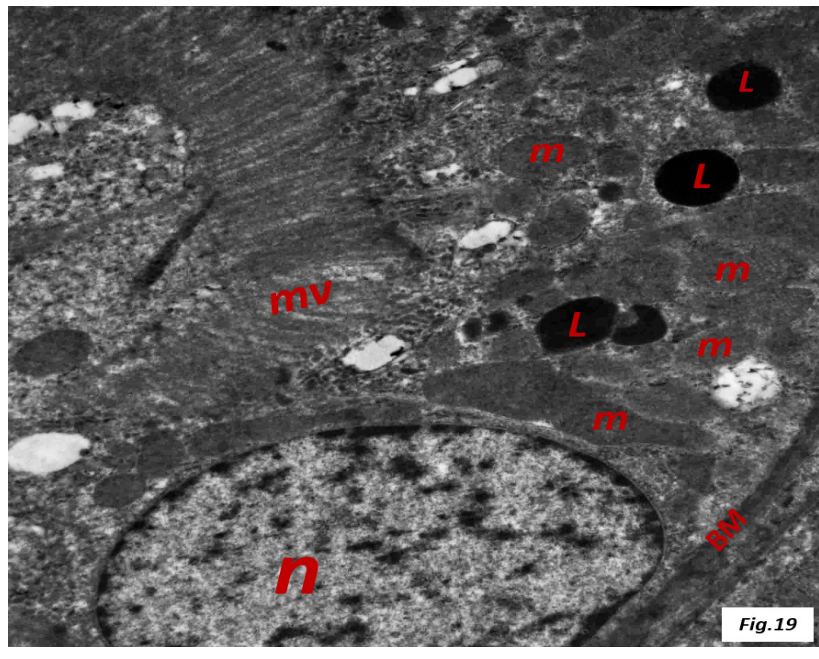

Fig. 19: An electron micrograph of a section of the renal cortex of a rat of group III showing a lining cell of PCT having euochromatic nucleus (n). Notice the swollen mitochondria (m), lysosomes (L) and preserved apical microvilli (mv). Note also the thickened lining basement membrane (BM). (TEM x2500)

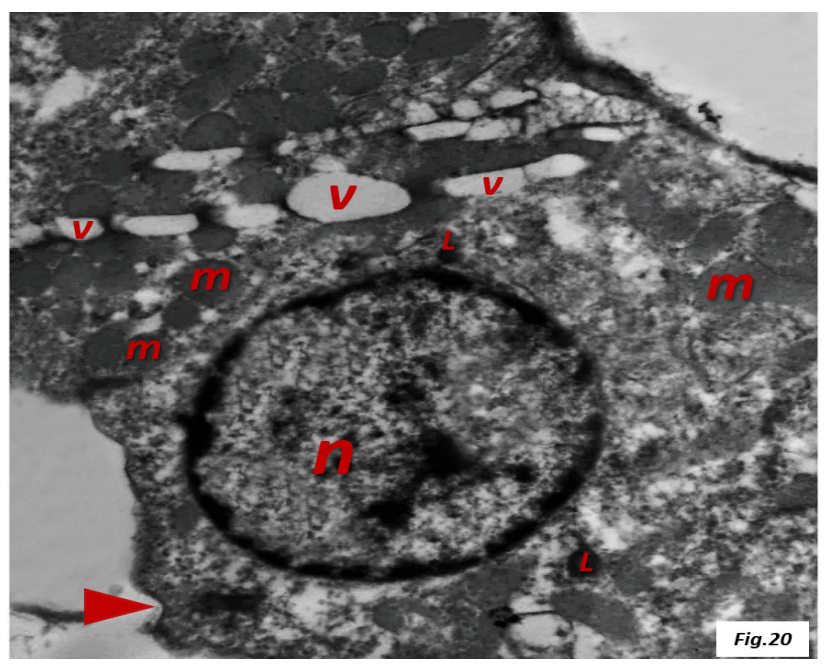

Fig. 20: An electron micrograph of a section of the renal cortex of a rat of group III showing a lining cell of DCT with euochromatic nucleus (n) surrounded by mitochondria (m), lysosomes (L) and variable sized vacuolar spaces $(v)$. Notice the irregular cell membrane $(\boldsymbol{\Delta})$ ). (TEM $\mathrm{x} 3000)$

Table 1: comparing Serum creatinine level among the three groups showing highly significant $(* *) P$ values

\begin{tabular}{cccc}
\hline & $\begin{array}{c}\text { Group I } \\
\text { (Control } \\
\text { Group) }\end{array}$ & $\begin{array}{c}\text { Group II } \\
\text { (AAS } \\
\text { Group) }\end{array}$ & $\begin{array}{c}\text { Group III } \\
\text { (AAS+Taurine } \\
\text { Group) }\end{array}$ \\
\hline $\begin{array}{c}\text { Serum creatinine level } \\
\text { Mean } \pm \text { SD } \\
\text { (in mg/dl) }\end{array}$ & $0.45 \pm 0.016$ & $0.73 \pm 0.07$ & $0.51 \pm 0.04$ \\
Between Group & & \\
I and II & $P=0.000007$ \\
T test $\quad$ Between Group & $P<0.001^{* *}$ \\
II and III & $P=0.0005$ \\
Between Group & $P<0.001^{* *}$ \\
I and III & $P=0.0006$ \\
& & $P<0.001^{* *}$ \\
\hline
\end{tabular}




\section{Serum Creatinine Levels}

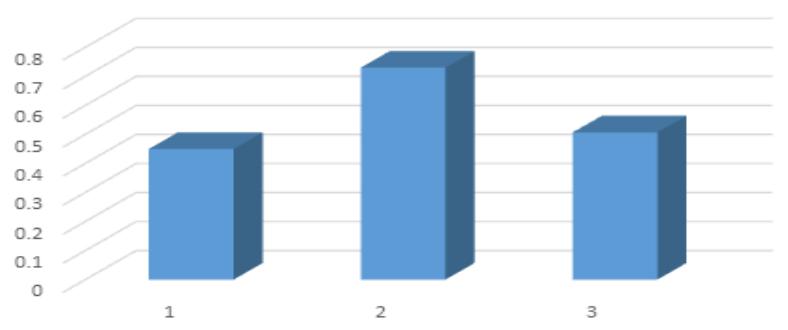

Histogram 1: demonstrating comparison between the three groups as regards serum creatinine levels.

Table 2: comparing BUN level among the three groups showing significant $(*)$ and highly significant $(* *) P$ values

\begin{tabular}{cccc}
\hline & $\begin{array}{c}\text { Group I } \\
\text { (Control } \\
\text { Group) }\end{array}$ & $\begin{array}{c}\text { Group II } \\
\text { (AAS } \\
\text { Group) }\end{array}$ & $\begin{array}{c}\text { Group III } \\
\text { (AAS+Taurine } \\
\text { Group) }\end{array}$ \\
\hline BUN level & & \\
Mean \pm SD & $19.99 \pm 0.18$ & $25.98 \pm 1.13$ & $20.66 \pm 0.73$ \\
(in mg/dl) & & \\
Between Group & & $P=0.00026$ E-8 \\
I and II & & $P<0.001^{* *}$ \\
T test $\quad$ Between Group & & $P=0.00027$ E-6 \\
II and III & & $P<0.001^{* *}$ \\
& Between Group & $P=0.012$ \\
I and III & $P<0.05^{*}$ \\
\hline
\end{tabular}

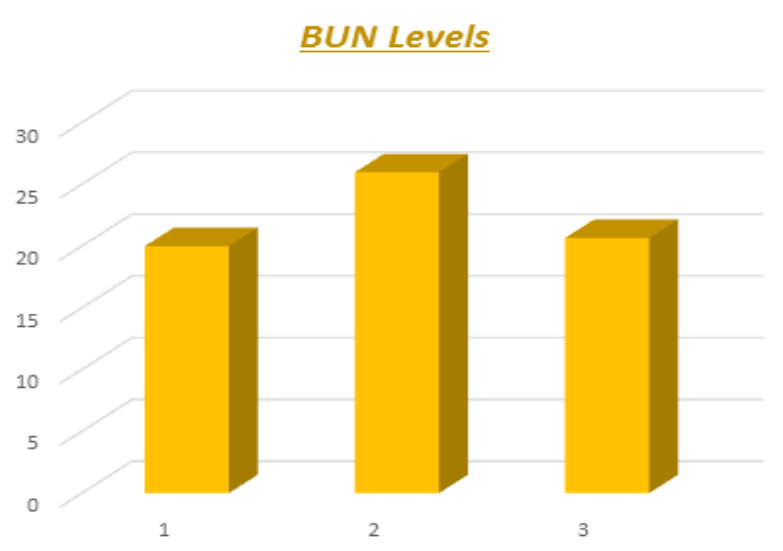

Histogram 2: demonstrating comparison between the three groups as regards BUN levels

\section{DISCUSSION}

Misuse of AAS has become a widespread health problem. Their unprescribed use in supraphysiological doses continues to grow among professional and recreational athletes, in addition to men seeking to improve their body image. Thus, a variety of adverse effects that impact many systems have recently evolved. However, among these various adverse effects, renal toxicity still remains one of the least discussed.
The present study revealed marked histopathological affection of rat renal cortex following six weeks exposure to AAS. However, congestion has been an almost fixed finding in this group regarding both glomerular capillaries and interstitial blood vessels. Similarly, Kahal and Allem, 2018 reported congestion of renal blood vessels and interstitial hemorrhage following AAS abuse in adult male mice and added that it persisted and even worsened after stopping treatment ${ }^{[24]}$.

This frequent finding could be attributed to the reported AAS induced cardiotoxicity where Vasilaki et al., 2016 further clarified that long-term administration of ND led to marked impairment of the global myocardial function indices, affecting mainly the diastolic function ${ }^{[25]}$. Thus, Tsitsimpikoua et al., (2016) linked the AAS induced cardiotoxicity to their reported renal affection, stating that chronic dilated cardiomyopathy could lead to kidney malfunction and reduced cardiac contractility might end up in renal failure in humans ${ }^{[8]}$.

Regarding the glomerular filtration barrier, the present study revealed marked distortion of its structure with frequently encountered areas of focal thickening of capillary basement membrane in addition to indistinct endothelial fenestrations. Moreover, the observed lesion of glomerular basement membrane of the same group in the present study might also affect filtration barrier with subsequent exacerbation of protein leakage. Moreover, podocytes had irregular nuclei with notable effacement of their foot processes. Kriz et al., (2013) stated that shortening, widening, effacement and retraction of foot processes with subsequent reduction of filtration slits is a common podocyte reaction following its injury[26]. Shankland et al., (2014) added that, if the initial injury to podocyte is severe, it may detach from the GBM and be washed away in the glomerular filtrate or undergo apoptosis leaving areas of bare glomerular basement membrane, which are foci for adhesions to parietal cells of Bowman's capsule ${ }^{[27]}$. Moreover, Jefferson and Shankland (2014) further clarified that these adhesions lead to loss of separation of the glomerular tuft from Bowman's capsule with subsequent segmental glomerulosclerosis ${ }^{[28]}$. This might explain the obliteration of Bowman's space reported in this study in the same experimental group.

Moreover, a link between glomerular damage and tubular interstitial injury has been previously clarified, where podocyte damage led to massive plasma protein leakage into the tubules. These proteins were reabsorbed by the PCT with subsequent secretion of mediators including; monocyte chemoattractant protein type 1, platelet-derived growth factor and endothelin, towards the interstitium. These mediators give rise to an inflammatory reaction leading to interstitial fibrosis ending up with tubular degeneration ${ }^{[29]}$.

In the present study, both PCT and DCT revealed marked histoarchitectural affection. Proximal convoluted tubules appeared with irregular cellular lining pattern 
resting on relatively thickened basement membrane enclosing ill-defined lumen. Ultrastructural examination of their lining cells revealed marked affection including; cytoplasmic vacuolation up to rarefication, dilated disorganized mitochondria, shrunken nuclei and destructed microvilli and subsequent exfoliation of nuclei and cellular debris seen in their lumina. Distal convoluted tubules which appeared lined by shrunken darkly stained nuclei together with rarefied ones. Ultrastructural degenerative signs including shrunken nuclei with peripheral chromatin clumping, ballooned mitochondria together with evident extracellular bands of fibrous tissue.

Similarly; Hasso, (2009) noted vacuolar degeneration of the lining epithelium of PCT with sloughing and necrosis of the epithelial cells and engorgement of many interstitial blood vessels in male rabbits following ND administration for 2 months duration ${ }^{[30]}$.

Sood et al., (2011) added that necrotic nuclei and detachment of brush border denote functional impairment of the urinary reabsorption. This necrosis could be attributed to mitochondrial damage and subsequent cellular ATP depletion $^{[31]}$. Moreover, mitochondrial damage can lead to intracellular oxidative stress and elevated ROS levels produced by impairment of the mitochondrial electron transport chain ${ }^{[32]}$.

Brenu et al., (2011) stated that, supraphysiological doses of ND enhance the production of the inflammatory cytokines, interleukin-1beta (IL-1 $\beta$ ) and tumor necrosis factor- $\alpha$ (TNF- $\alpha)$ in human peripheral blood lymphocyte cultures in vitro ${ }^{[33]}$. Tumor necrosis factor- $\alpha$ has been defined as a cytotoxic cytokine that induces apoptosis in many cells, including renal tubular cells either through interaction with its membrane-bound receptor or by inducing disturbances in the mitochondrial membrane and release of cytochrome $\mathrm{C}^{[34]}$. In addition, Riezzo et al., (2014) reported that long-term administration of ND, led a reduction of antioxidant enzyme activity resulting in oxidative renal cell damage due to its decreased ability to scavenge toxic hydrogen peroxide and lipid peroxides ${ }^{[19]}$.

Hasso, (2009) noted enlargement and increased cellularity of the renal corpuscles in male rabbits following ND administration for 2 months duration ${ }^{[30]}$. Moreover, the study of Zeier M et al. (1998) documented that testosterone amplifies the compensatory growth of residual nephrons and such nephron hypertrophy may set the stage for accelerated progression of renal disease ${ }^{[35]}$. However, AAS induced PCT increased diameter and luminal debris detected in the present study could also be attributed to the observed congestion where Hemmi et al., (2015) stated that renal congestion was accompanied by an increase in diameter of PCT and obstruction of their lumina by swollen cells and ischemia-associated cell debris ${ }^{[36]}$.
On the other hand, renal cortex of group III rats given both AAS and taurine simultaneously showed almost preserved normal histoarchitecture. Regarding, glomerular filtration barrier, capillary basement membrane appeared regular with many areas of preserved endothelial fenestrations. However, podocytes still had some nuclear irregularity but their foot processes almost mimicked those of the control ones. Similarly; Al Kahtani et al., (2016) reported that taurine pretreatment exerted protective effects against aluminum chloride induced nephrotoxicity and preserved the overall glomerular vascular architecture of the kidney by maintaining podocyte integrity and tight foot process attachment to glomerular basement membrane thus improving microcirculation ${ }^{[37]}$. They added that prevention of podocyte damage with taurine likely leads to sustained renal function owing to the fact stated by Kriz et al., (1999) that the replication capability of podocytes is limited in the adult and cannot be replaced once they undergo degeneration $^{[38]}$.

As for the convoluted tubules of the same group, they showed some signs of preserved architecture where PCT lining cells retained their regular apical microvilli and longitudinal arrangement of mitochondria. Those of the DCT lacked the rarefied cytoplasmic appearance observed in those of group II and had euochromatic nuclei surrounded by mitochondria, some lysosomes and few persistent vacuolar spaces. Similarly, Heidari, et al. (2019) reported that, taurine protected mice kidney against acute tubular necrosis, tubular casts and tubular dilation caused by colistin, a last line antibiotic used in drug-resistant infections, and markedly preserved kidney mitochondrial function $^{[39]}$. Moreover, through its antioxidant power, taurine alleviated the oxidative renal injury induced by fipronil, a commonly used pesticide, and normalized serum levels of kidney function biomarkers ${ }^{[40]}$. This antioxidant power was attributed to the taurine associated decrease in lipid peroxidation and preservation of both cytochrome P450 content and glutathione metabolizing enzymes ${ }^{[41]}$.

Thus, taurine exerted a protective effect against AAS induced damage to renal cortex.

\section{CONCLUSION}

Misuse ofAAS had hazardous effects on the renal cortical structure with subsequent renal functional deterioration. Thus, community-based prevention programs targeting AAS-use at the gyms and other settings must be done as an attempt in solving this growing public health problem. On the other hand, taurine showed a marked reno-protective role of in preventing or at least ameliorating the AAS induced renal toxicity. Thus, taurine administration would be also of great help to protect AAS users against possible renal hazards in case their AAS use was inevitable. 


\section{CONFLICT OF INTEREST}

No conflict of interest

\section{REFERENCES}

1. Achar S., Rostamian A. and Narayan S.M. (2010): Cardiac and metabolic effects of anabolicandrogenic steroid abuse on lipids, blood pressure, left ventricular dimensions and rhythm. Am. J. Cardiol.; 106: 893-901.

2. Breuner, C.C. (2014): Performance-enhancing substances. Adolesc. Med. State Art. Rev.; 25(1): 113-125.

3. Santos M.A., Oliveira C.V. and Silva A.S. (2014): Adverse cardiovascular effects from the use of anabolic-androgenic steroids as ergogenic resources. Subst. Use Misuse; 49: 1132-1137.

4. Vanberg P. and Atar D. (2010): Androgenic anabolic steroid abuse and the cardiovascular system. Handb. Exp. Pharmacol.; 411-457.

5. Juhn, M.S. (2003): Popular sports supplements and ergogenic aids. Sports Med.; 33: 921-939.

6. Hageloch W., Appell H.J. and Weicker H. (1988): Rhabdomyolysis in a bodybuilder using anabolic steroids. Sport verletz. Sportschaden.; Sep:2(3):122-125.

7. Merino García E., Borrego Utiel F.J., Martínez Arcos M.Á., et al. (2018): Kidney damage due to the use of anabolic androgenic steroids and practice of bodybuilding. Nefrologia; Jan - Feb: 38(1): 101-103.

8. Tsitsimpikou C., Vasilaki F., Tsarouhas K., et al. (2016): Nephrotoxicity in rabbits after long-term Nandrolone Decanoate administration. Toxicology Letters; 259: 21-27

9. Gaofeng W., Jiancheng Y., Changmian S., et al. (2009): Effect of taurine on alcoholic liver disease in rats. Amino Acids; 36: 457-464.

10. Abebe W. and Mozaffari M.S. (2011): Role of taurine in the vasculature: an overview of experimental and human studies. Am. J. Cardiovasc. Dis.; 1: 293-311.

11. Murakami S. (2014): Taurine and atherosclerosis. Amino Acids; 46: 73-80.

12. Jagadeesan G. and Sankarsami Pillai S. (2007): Hepatoprotective effects of taurine against mercury induced toxicity in rats. J. Environ. Biol.; Oct: 28(4): 753-756.

13. Manna P., Sinha M. and Sil P.C. (2008): Amelioration of cadmium-induced cardiac impairment by taurine. Chem. Biol. Interact.; Jul 30: 174(2): 88-97.
14. Manna P., Sinha M. and Sil P.C. (2009): Taurine plays a beneficial role against cadmium-induced oxidative renal dysfunction. Amino Acids.; Mar: 36(3): 417-428.

15. Tabassum H., Rehman H., Banerjee B.D., et al. (2006): Attenuation of tamoxifeninduced hepatotoxicity by taurine in mice. Clin. Chim. Acta.; Aug: 370 (1-2): 129-136.

16. Das J., Ghosh J., Manna P., et al. (2008): Taurine provides antioxidant defense against NaFinduced cytotoxicity in murine hepatocytes. Pathophysiology.; Oct: 15(3): 181-190.

17. Lin S., Yang J., Wu G., et al. (2010): Preventive effect of taurine on experimental type II diabetic nephropathy. J. Biomed. Sci.; Aug 24: 17 Suppl 1: S46.

18. Rosca A.E., Stoian I., Badiu C., et al. (2016): Impact of chronic administration of anabolic androgenic steroids and taurine on blood pressure in rats. Braz. J. Med. Bio.1 Res.; 49(6): e5116.

19. Riezzo I., Turillazzi E., Bello S., et al. (2014): Chronic nandrolone administration promotes oxidative stress, induction of pro-inflammatory cytokine and TNF- $\alpha$ mediated apoptosis in the kidneys of CD1 treated mice. Toxicol. Appl. Pharmacol.; Oct 1: 280(1): 97-106.

20. Parkinson A.B. and Evans N.A. (2006): Anabolic androgenic steroids: a survey of 500 users. Med. Sci. Sports Exerc.; Apr: 38(4): 644-651.

21. Ahmed M.A. (2015): Amelioration of nandrolone decanoate-induced testicular and sperm toxicity in rats by taurine: effects on steroidogenesis, redox and inflammatory cascades, and intrinsic apoptotic pathway. Toxicol. Appl. Pharmacol.; Feb 1: 282(3): 285-296.

22. Drury R. and Wallington E. (1980): Carleton's Histological Techniques. 5th edition. Oxford University Press. London, New York and Toronto. pp: 183-184.

23. Bancroft JD and Gamble M (2002): Theory and Practice of Histological Techniques. 5th edition. Churchill Livingstone. London, New York and Sydney. pp: 377-694.

24. Kahal A. and Allem R. (2018): Reversible effects of anabolic steroid abuse on cyto-architectures of the heart, kidneys and testis in adult male mice. Biomed. Pharmacother.; Oct: 106: 917-922.

25. Vasilaki F., Tsitsimpikou C., Tsarouhas K., et al. (2016): Cardiotoxicity in rabbits after long-term Nandrolone Decanoate administration. Toxicol. Lett.; Jan 22: 241: 143-151. 
26. Kriz W., Shirato I., Nagata M., et al. (2013): The podocyte's response to stress: the enigma of foot process effacement. Am. J. Physiol. Renal Physiol.; Feb 15: 304(4): F333-347.

27. Shankland S.J., Smeets B., Pippin J.W., et al. (2014): The emergence of the glomerular parietal epithelial cell. Nat. Rev. Nephrol.; 10: 158-173.

28. Jefferson JA and Shankland SJ. (2014): The pathogenesis offocal segmentalglomerulosclerosis. Adv. Chronic Kidney Dis.; Sep: 21(5): 408-416.

29. Kriz W. and Lemley K.V. (1999): The role of the podocyte in glomerulosclerosis. Curr. Opin. Nephrol. Hypertens.; Jul: 8(4): 489-497.

30. Hasso R.A. (2009): Histological Toxic Effect of Nandrolone Decanoate on the Kidney of Male Rabbits. MJBU; 27 (1): 19-22.

31. Sood P.K., Nahar U. and Nehru B. (2011). Curcumin attenuates aluminum-induced oxidative stress and mitochondrial dysfunction in rat brain. Neurotox. Res.; 20: 351-361.

32. Indo H.P., Davidson M., Yen H.C., Suenaga S., et al. (2007): Evidence of ROS generation by mitochondria in cells with impaired electron transport chain and mitochondrial DNA damage. Mitochondrion; 7: 106-118.

33. Brenu E.W., McNaughton L. and MarshallGradisnik S.M. (2011): Is there a potential immune dysfunction with anabolic androgenic steroid use?: A review. Mini-Rev. Med. Chem.; 11: 438-445.

34. Misseri R., Meldrum D.R., Dinarello, et al. (2005): TNF-alpha mediates obstruction-induced renal tubular cell apoptosis and proapoptotic signaling. Am. J. Physiol. Renal Physiol.; 288: F406-F411.
35. Zeier M., Schönherr R., Amann K., et al. (1998): Effects of testosterone on glomerular growth after uninephrectomy, Nephrol. Dial. Transplant.; 13 (9): 2234-2240.

36. Hemmi S, Matsumoto N., Jike T., et al. (2015): Proximal tubule morphology in rats with renal congestion: a study involving the in vivo cryotechnique. Med. Mol. Morphol.; Jun: 48(2): 92-103.

37. Al Kahtani M.A., Abdel-Moneim A.M., and ElSayed W.M. (2014): The influence of taurine pretreatment on aluminum chloride induced nephrotoxicity in Swiss albino mice. Histol. Histopathol.; 29: 45-55.

38. Kriz W., Elger M., Hosser H., et al. (1999): How does podocyte damage result in tubular damage? Kidney Blood Press. Res.; 22 (1-2): 26-36.

39. Heidari R., Behnamrad S., Khodami Z., et al. (2019): The nephroprotective properties of taurine in colistin-treated mice is mediated through the regulation of mitochondrial function and mitigation of oxidative stress. Biomed. Pharmacother.; Jan: 109: 103-111. Epub: 2018, Nov 2.

40. Abdel-Daim M.M., Dessouki A.A., Abdel-Rahman H.G., et al. (2019): Hepatorenal protective effects of taurine and $\mathrm{N}$-acetylcysteine against fipronilinduced injuries: The antioxidant status and apoptotic markers expression in rats. Sci. Total Environ.; Feb 10: 650(Pt 2): 2063-2073. Epub 2018 Sep 25.

41. Messina S.A. and Dawson R. Jr. (2000):Attenuation of oxidative damage to DNA by taurine and taurine analogs. Adv. Exp. Med. Biol.; 483: 355-367. 


\title{
الملخص العربى
}

\section{تأثير المنشطات البنائيه على التركيب الهيستولوجى للقشرة الكلوية

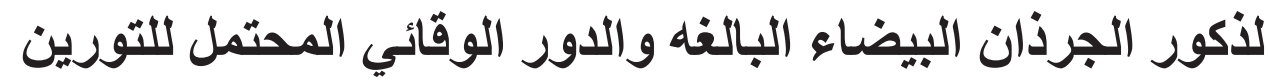

\author{
مارى رفعت اسحق \\ قسم التشريح وعلم الأجنة، كلية الطب، جامعة عين شمس
}

مقدمة: لقد أصبح سوء إستخدام المنشطات الذكوريه البنائيه مشكلة صحية واسعه النطاق بما يتبعها من آثار سلبيه على

اجهزه الجسم المتعدده. على صعيد آخر، يبقى تأثنير ها السلبى على الكليه أحد المشكلات الأقل بحنّل. الهدف من العمل: در اسة تأثير سوء إستخدام الناندرولون ديكانوات على التركيب النسيجى و وظيفه القشرة الكلوية ودر اسه الدور الوقائي المحتمل للتورين. المو اد و الطرق: استخدم في هذه الدر اسة سته و ثلاثون من ذكور الجرذان البيضاء ، تتر اوح أعمار هم ما بين 6-4 أشهر ووزنهم من 200 إلى 250جم. تم تقسيم الحيو انات بالتساوي إلى ثلاث مجمو عات كالتالى: • المجمو عة الأولى (المجمو عة الضابطة): تنقسم إلى: O المجمو عة الفر عية1أ : مجمو عه ضابطه سلبيه o المجمو عة الفر عية1ب: تلقت الجرذان 0.5 مل من زيت السمسم حقنا فى العضل مرتين أسبو عياً لمدة ستة أسابيع. o المجموعة الفرعية1ج: تلقت الجرذان 100 مجم/كجم من التورين يومياً عن طريق الفم لمدة ستة أسابيع. • المجموعة الثانية (مجمو عة الناندرولون ديكانوات): أعطيت الجرذان 5 مجم/كجم من الناندرولون ديكانوات مذاب في زيت السمسم مرتين أسبو عياً لمدة ستة أسابيع. • المجموعة الثالثة (مجموعة الناندرولون ديكانوات و التورين):أعطيت الجرذان كل من التورين و الناندرولون ديكانو ات بنفس الجرعات و المدة الزمنيه كالمجمو عة الفرعية 1ج و المجموعة الثانية على التو الي. في نهاية التجربة ، تم جمع عينات الدم الوريدي من وريد الذيل للفحوصات البيوكيميائية كما نم استخر اج الكلى ومعالجتها إستعدادا للفحص المجهري الضوئى و الإلكترونى. النتائج: كثنف فحص عينات المجمو عة الثانية إحتقانا ملحوظا فى قثره الكليه بالإضافه إلى طمس لمساحه فر اغ كبسوله بومان و تجويفات الأنابيب القريبة والبعيدة بالإضافه إلى إختلالا واضحًا فى البنية التحتية لحاجز الترشيح الكبيبي و الخلايا المبطنة للأنابيب. كما أوضحت النتائج البيوكيميائية لهذه المجمو عه تغير ات ذات دلالة إحصائية. بينما أظهرت المجمو عة الثالثة أن بنيه الكبيبات و الأنابيب الكلويه بدت طبيعيه فيما عدا بعض التغيير ات الطفيفه. بالإضافه إلى تحسنا

$$
\text { ملحوظا فى النتائج البيوكيميائية لذات الجمو عه. }
$$

الخلاصة: أسفر إستخدام الناندرولون ديكانوات إلى تدهور فى بنيه و وظيفه القشرة الكلوية. أما عن التورين، فقد قام بحماية للكلى من هذا التدهور. لذا فيمكن إستخدام التورين لحماية مستخدمي المنشطات الذكوريه البنائيه من المخاطر لهابه المحتملة على الكلى في حال كان استخدامهم لهذه الأدوية أمر اً لا مفر منه. 